\title{
Nonalcoholic Fatty Liver Disease in South Asia
}

\author{
${ }^{1}$ Girish K Pati, ${ }^{1,2}$ Shivaram P Singh
}

${ }^{1}$ Department of Gastroenterology, Shri Ramachandra Bhanj Medical College, Cuttack, Odisha, India, ${ }^{2}$ Kalinga Gastroenterology Foundation, Cuttack, Odisha, India

\begin{abstract}
Nonalcoholic fatty liver disease (NAFLD) is the most common chronic liver disease in the West, and is also increasing alarmingly in South Asia, reaching an epidemic proportion of $30 \%$ because of epidemic of obesity and metabolic syndrome (MS) in younger South Asians in the last two decades. Prevalence of MS and fatty liver is escalating in geometric progression in South Asian countries, such as India, Pakistan, Sri Lanka, Bangladesh, Nepal, Bhutan, Burma, and Maldives because of sedentary lifestyle, poor health awareness, socioeconomic growth, affluence, urbanization, and dietary westernization. Almost $20 \%$ of world's population resides in South Asia, making it the most populous and most densely populated geographic region in the world, thereby having most of MS and NAFLD cases within its territory. The risk factors and course of NAFLD do not differ between South Asians and other ethnic populations, but the obesity epidemic is more recent in South Asia than elsewhere in the world. Nonalcoholic fatty liver disease may progress through stages of simple bland steatosis, nonalcoholic steatohepatitis (NASH), hepatic fibrosis, cirrhosis, and finally hepatocellular carcinoma (HCC). It is frequently associated with obesity, MS, dyslipidemia, insulin resistance (IR), and type-2 diabetes mellitus (DM). Nonalcoholic fatty liver disease is frequently diagnosed with abdominal ultrasonography (US) study. Despite its high prevalence in the community till now, no definitive pharmacotherapy is available for NAFLD. However, modification of risk factors, such as dyslipidemia, control of diabetes, and weight reduction do help to some extent. The nonobese South Asians are also at increased risk of having NAFLD and NASH as, despite of absence of frank obesity in South Asians, they are metabolically more obese compared to other ethnic population and more prone to develop NAFLD-related complications. Therefore, the cost-effective US abdomen should be included in the list of tests for persons undergoing preemployment or master health checkups for early diagnosis of NAFLD in this resource-constraint South Asian region, so that early necessary measures can be undertaken to reduce NAFLD associated morbidity and mortality in the community.
\end{abstract}

Keywords: Fatty liver, Hepatocellular carcinoma, Nonalcoholic fatty liver disease, nonalcoholic steatohepatitis, Physical activity, South Asia.

How to cite this article: Pati GK, Singh SP. Nonalcoholic Fatty Liver Disease in South Asia. Euroasian J Hepato-Gastroenterol 2016;6(2):154-162.

Source of support: Nil

Conflict of interest: None

Copyright and License information: Copyright (C) 2016; Jaypee Brothers Medical Publishers (P) Ltd. This work is licensed under a Creative Commons Attribution 3.0 Unported License. To view a copy of this license, visit http://creativecommons.org/licenses/by/3.0/

\section{INTRODUCTION}

Nonalcoholic fatty liver disease (NAFLD) is a clinicohistopathological entity in which liver histology resembles alcohol-induced liver injury, which occurs in patients who never drink or drink less alcohol $(<20 \mathrm{~g}$ /day in male; $<10 \mathrm{~g} /$ day in female). ${ }^{1}$ Fatty liver by definition means fatty infiltration of at least $5 \%$ of the liver tissue. ${ }^{2}$ Nonalcoholic fatty liver disease cases may progress through stages of simple bland steatosis, nonalcoholic steatohepatitis (NASH), hepatic fibrosis, cirrhosis, and finally hepatocellular carcinoma (HCC). Patients with NASH have most of the component of metabolic syndrome (MS), and prone to suffer from cardiac, cerebrovascular diseases, diabetes-related complications, and liver-related morbidities and mortality. ${ }^{3}$ Prior report suggests that $80 \%$ of cryptogenic cirrhostics suffer from NASH. ${ }^{4}$ In the current era, NAFLD is considered to be the most common liver disease in the western countries, affecting 20 to $30 \%$ of the general population ${ }^{5,6}$ and is also increasing alarmingly in South Asian countries, with an epidemic proportion of $30 \%$ due to epidemics of obesity and MS in the younger South Asians in the last two decades. ${ }^{7}$ Prevalence of MS and fatty liver is escalating in geometric progression in South Asian countries, especially India, Pakistan, Sri Lanka, Bangladesh, and Nepal because of sedentary lifestyle, poor health awareness, socioeconomic growth, affluence, urbanization, and dietary westernization. Almost $20 \%$ of the world's

Address reprint requests to: Shivaram P Singh, Professor, Department of Gastroenterology, Shri Ramachandra Bhanj Medical College Cuttack, Odisha, India, e-mail: fattyliver@gmail.com 
population resides in South Asia, making it the most populous and most densely populated geographic region in the world, and South Asia harbors a large number of MS and NAFLD cases within its territory. The risk factors and course of NAFLD probably do not differ between South Asians and other ethnic populations, but the recent obesity epidemic in South Asia may lead to increased occurrence of fatty liver in this part of the world. Earlier studies have confirmed that the South Asians are at higher risk to suffer from obesity-related morbidity and mortality compared to other ethnic groups, including the Caucasians. ${ }^{8}$ Nonalcoholic fatty liver disease is considered to be the hepatic manifestation of MS, and commonly associated with insulin resistance (IR) and other components of MS, such as diabetes mellitus (DM), hypertension, central obesity, hypertriglyceridemia, and low high-density lipoprotein (HDL) cholesterol. ${ }^{9}$ Nonalcoholic fatty liver disease is among the most common etiologies of unexplained transaminitis, in particular raised alanine aminotransferase (ALT) has been adopted as a surrogate marker of NAFLD in epidemiological studies. ${ }^{10}$ The prevalence of NAFLD in the West, ${ }^{11}$ Asia,, 12 type-2 DM patients, ${ }^{13}$ and obese population ${ }^{14}$ varies from 24 to 42,5 to 40,50 to 75, and 35 to $75 \%$ respectively. Men out-numbered the females in having NAFLD in most of the published series. ${ }^{11,15}$ Pathogenesis of NAFLD involves a multihit hypothesis; initially hepatic steatosis occurs due to IR, followed by hepatocellular inflammation due to oxidative stress. ${ }^{16}$ Current report suggests that altered gut microbiome may be associated with higher endotoxemia and lower cecal bifidobacterium contributing to diabetes, obesity, and NASH. ${ }^{17}$ Most patients with NAFLD are usually asymptomatic, or may present with fatigability, heaviness, and discomfort on the right side of the upper abdomen. ${ }^{18}$ Nonalcoholic fatty liver disease is usually diagnosed by abdominal ultrasonography (US) imaging. The ultrasound features of NAFLD include increased hepatic echogenicity, vascular blurring, and deep attenuation of US signals. These US features had good accuracy in detecting fatty liver and had good correlation with visceral obesity and MS. ${ }^{19,20}$ Magnetic resonance imaging (MRI) can quantify the triglycerides stores in liver, which may be useful in assessing the efficacy of therapeutic intervention. ${ }^{21}$ For assessment of disease severity, liver histology study is required, which can clearly differentiate NAFLD from NASH and liver fibrosis, which is never possible by other available imaging modalities. Despite its high prevalence in the community till now, no definitive pharmacotherapy is available for NAFLD. However, modification of risk factors, such as dyslipidemia, control of diabetes, and weight reduction do help to some extent. ${ }^{22}$ Lifestyle changes and weight loss remain the mainstay of therapy, and are effective in improving liver function tests and histology. Treatment strategies for NAFLD have resolved around identification and treatment of frequent associated metabolic conditions, such as diabetes, obesity, dyslipidemia, hypertension, improving IR by weight loss, exercise, and/or pharmacotherapy, and by using hepatoprotective drugs, such as antioxidants, vitamin $\mathrm{E}$, high-dose ursodeoxycholic acid to protect liver from secondary insults. ${ }^{23,24}$ Prior study suggested an emerging role for bariatric surgery, resulting in both biochemical and histological improvements in patients with NASH. ${ }^{25}$ Bariatric surgery can cure diabetes in $\sim 66 \%$, and reverse NASH in $\sim 80 \%$ of cases; whereas effect on fibrosis is less clear. ${ }^{26}$ Compared to West, in South Asian countries including India, many cases suffer from acute viral hepatitis $\mathrm{A}$ and $\mathrm{E}$ and chronic viral hepatitis $B$ and $C$ because of densely populated regions in this part of the world, except two South Asian countries, such as Pakistan and Nepal, where chronic viral hepatitis B almost eradicated. Whenever cases with NAFLD also get infection from acute or chronic viral hepatitis infection, they rapidly deteriorate and may land in acute or chronic liver failure and increased morbidities and mortalities. As this South Asian countries are resource-constrained poor developing countries where a lot of people are illiterate and do not adopt safety lifestyle measure, so they are prone to suffer from these potential viral infections and poor outcome. Therefore, it becomes imperative that the primary physicians in the South Asian countries should be well aware regarding these potential fatal liver diseases and hepatotrophic viral infection in this region of the world so that they can well guide their patients to adopt healthy preventive lifestyle measures and that they will suffer less commonly from these preventable liver-related diseases.

\section{EPIDEMIOLOGY AND DETERMINANTS}

The initial astute observation of relationship between central obesity and IR with high prevalence of diabetes and cardiovascular risk in South Asians compelled the attention of whole world on the high prevalence of MS in this particular region. ${ }^{27}$ Studies from India ${ }^{28,29}$ and Sri Lanka $^{30,31}$ have led authors to conclude that the prevalence of NAFLD in South Asia varies from 9 to $45 \%$. The lowest prevalence (8.7-18\%) of NAFLD was observed in physically active, poor, lean persons residing in rural region. ${ }^{29,31}$ Prior report suggested that the presence of central obesity, visceral fat, and cardiovascular risk factors is higher in South Asians compared to Caucasians with similar body mass index (BMI) and lower average waist circumference (WC). ${ }^{32}$ For equivalent levels of overnutrition, South Asians are more prone to MS, type-2 DM, and 
NAFLD than Europeans because of differences in body composition, particularly adiposity and muscle bulk. Lifestyle changes are likely to account for the pandemics of fatty liver, obesity, and type-2 diabetes in South Asia. Though South Asians are not more overt obesity compared to other ethnic populations, but they were metabolically more obese compared to other ethnic groups. ${ }^{33}$ Clustering of cardiovascular risk factors in South Asians was first reported from UK. ${ }^{34}$ South Asians usually have higher percentage of visceral body fat, ${ }^{35,36}$ abdominal obesity, ${ }^{35,36} \mathrm{IR}^{37}$ hyperinsulinemia, ${ }^{38}$ and low muscle mass $^{39}$ compared to other ethnic populations; therefore they are more prone to suffer from NAFLD and MS. Studies in North America have noted an ethnic predisposition for occurrence of NAFLD in South Asian Indian males, Hispanics, and East Asians, despite similarities in metabolic risk factors between different races. ${ }^{40,41}$ In particular, central obesity/truncal obesity is much more common in South Asians and also evident in nonobese South Asians. Further, thick subcutaneous adipose tissue in South Asians may be a key correlate of IR. ${ }^{42,43}$ South Asians usually have thick subscapular subcutaneous fat since birth, therefore commonly associated with hyperinsulinemia and suffer from NAFLD and MS at an early age compared to other ethnic population. ${ }^{44}$ Genetic propensity for development of dyslipidemia, obesity, and diabetes has been observed in South Asians. ${ }^{45-48}$ Various studies showed that South Asians had increased prevalence of hyperglycemia, dyslipidemia, IR, procoagulant activity, and large adipocytes. ${ }^{49-51}$ Other causative factors for development of MS and NAFLD in South Asians are less physical activity, spending much time watching televisions and computer games, increased consumption of energy-rich imbalanced food, junk food, soft drink, fast food compared to other ethnic population. ${ }^{49,52,53}$ South Asians usually consume comparatively lesser amount of omega-3 polyunsaturated fatty acids (PUFA), monosaturated fatty acids, and more amount of omega-6 polyunsaturated fatty acids compared to British Caucasians. ${ }^{54}$ Prior study confirmed the relationship of NASH with low serum adiponectine levels in Asians. ${ }^{11}$ Schwimmer et a ${ }^{55}$ suggested that familial factors might act as a major risk factor for occurrence of NAFLD in South Asians. All these abovementioned factors and determinants play significant role in increased prevalence of MS, NAFLD, type-2 DM, and cardiovascular morbidity and mortality in South Asians. In most Western studies, the mean age of presentation of NAFLD patients was 50 to 55 years, $1,10,56$ which was higher compared to NAFLD cases in South Asian regions, with mean age of presentation at 45 years in Pakistan, ${ }^{57}$ and 38 years in India. ${ }^{58}$ Mean BMI of Western population ${ }^{1,56}$ with NAFLD was 30 to $35 \mathrm{~kg} / \mathrm{m}^{2}$, which was in sharp contrast to South Asians with NAFLD, with mean BMI of $29 \mathrm{~kg} / \mathrm{m}^{2}$ in India ${ }^{58,59}$ and $27 \mathrm{~kg} / \mathrm{m}^{2}$ in Sri Lanka. ${ }^{30}$ Presence of excess dorsocervical fat and excess fat deposition under the skin (double chin) signify heightened risk for development of MS in South Asian Indians and can be used as a phenotypic marker. ${ }^{59}$ South Asian Indians are more prone to develop IR, MS, type-2 $\mathrm{DM}$, and coronary heart disease because of presence of higher body fat, abdominal (central) adiposity, and higher high-sensitivity C-reactive protein (hs-CRP) levels compared to white Caucasians. ${ }^{60,61}$ Study by Babusik et $\mathrm{al}^{62}$ at Kuwait reported that in South Asians, increased age, male gender, hyperglycemia, increased WC, and waist height ratio were significantly associated with hepatic steatosis.

\section{PREVALENCE AND ASSOCIATION IN DIFFERENT SOUTH ASIAN COUNTRY}

\section{India}

Prevalence of NAFLD in India would approximate prevalence of MS since most of metabolic covariates of NAFLD are highly prevalent in Indians. ${ }^{63}$ Prior study indicated that the prevalence of MS in India is 11 to $41 \%{ }^{63,64}$ The community prevalence of NAFLD in India varies from 5 to $28 \% .{ }^{65-67}$ Almost 30 to $65 \%$ of adult urban Indians are either overweight/obese or have abdominal obesity. ${ }^{60}$ Common age of presentation of NAFLD in Indians is 30 to 50 years. ${ }^{68}$ Diabetes and central obesity are common predisposing factors, while IR is detected almost universally. ${ }^{65-67,69}$ A study conducted by Bajaj et al, ${ }^{70}$ at New Delhi, reported that subjects with NAFLD had significantly higher degree of BMI, WC and hip circumference, fasting hyperglycemia, fasting hyperinsulinemia, hypercholesterolemia, and hypertriglyceridemia. A study by Nigam et al, ${ }^{71}$ at New Delhi, demonstrated that presence of higher BMI, high-sensitive C-reactive protein (hs-CRP) and $\mathrm{WC}$, and fasting hyperglycemia, hypercholesterolemia, hypertriglyceridemia, hypertension, and MS were significantly and independently associated with NAFLD compared to controls. One recent study by Singh et $\mathrm{al}^{72}$ at Cuttack, Odisha revealed that Indians with NAFLD were younger, had lower BMI, and prevalence of DM, MS but similar necroinflammatory activity and fibrosis score compared to the West. Transaminitis is neither a reliable marker of NASH nor fibrosis and should not influence the decision for liver biopsy in these patients. ${ }^{72}$ The common primary diseases for which these patients sought consultation were nonulcer dyspepsia ( $54.5 \%)$ and irritable bowel syndrome (29.4\%). ${ }^{72}$ A study by Kumar et al ${ }^{73}$ in India reported that the lean NAFLD cases were less commonly diabetic $(p=0.01)$ and had significantly lesser degree of fasting hyperinsulinemia, homeostasis model 
assessment insulin resistance (HOMA-IR), and MS $(p<0.001)$ compared to obese NAFLD cases. The serum lipid profile was almost similar between the obese and lean NAFLD cases and $89 \%$ of lean NAFLD cases had dyslipidemia. The lean NAFLD cases had significantly lesser degree of hepatic necroinflammatory activity $(\mathrm{p}=0.05)$ and mild-to-moderate fibrosis $(\mathrm{p}<0.001)$, despite similar incidence of dyslipidemia, steatohepatitis, and advanced fibrosis compared to obese cases. A recently published study by Singh et $\mathrm{al}^{74}$ in coastal eastern India reported that the prevalence of diabetes and prediabetes was six times more common in NAFLD patients compared to healthy controls. Moreover, NAFLD patients with diabetes had higher metabolic risk factors, such as large waistline, hypertension, high triglyceride levels, and increased IR. Diabetes or prediabetes patients per se do not have histologically severe disease, rather IR plays an important role in increasing the severity of the disease. Another study by Singh et $\mathrm{al}^{75}$ in coastal Eastern India stated that nearly half of NAFLD patients in this coastal part had no IR; one-third of them had significant fibrosis, and therefore, the author opined that NAFLD might be a heterogeneous disease and sole IR might not be the sole etiologic factor for progression of NAFLD; rather some unknown factors might play role in increasing severity of NAFLD cases.

\section{Sri Lanka}

Studies from Sri Lanka have reported a NAFLD prevalence of $32.6 \%$ in an urban community ${ }^{30}$ and $18 \%$ in a predominantly Indian Tamil, rural, physically active, economically deprived estate worker community. ${ }^{31}$ Obesity, acanthosis nigricans, fasting hyperglycemia, IR, hypertension, hypertriglyceridemia, and transaminitis were independently associated with NAFLD. ${ }^{30}$ Male sex, high BMI, high WC, hypertension, and hyperglycemia were significantly associated with NAFLD. ${ }^{31}$ Sri Lankan studies have shown that the risk of developing diabetes within 3 years of NAFLD diagnosis increases 3 to 4 fold, even among lean individuals. A person with NAFLD was 1.6 times more likely to develop DM compared to a person without NAFLD. ${ }^{30}$ A study by De Hewavisenthi et $\mathrm{al}^{76}$ showed that $35.1 \%$ of study population had NASH, with majority (79\%) cases observed in male and NASH was associated with increased prevalence of DM (55\%), obesity (52\%), hyperlipidemia (54\%), family history of risk factors $(66 \%)$, and consumption of high dietary fat intake (66\%).

\section{Pakistan}

The prevalence of NAFLD in rural and urban areas in Pakistan among lower, middle, and higher societies were $9,15,27 \%$, and $21,27,42 \%$ respectively reflecting the effects of industrialization and urbanization on higher prevalence of fatty liver in urban higher societies. ${ }^{77}$ The prevalence of NAFLD in patients with type-2 DM and MS in Pakistani population was found to be $72.4 \%{ }^{78}$ A study by Niaz et $\mathrm{al}^{79}$ showed that $13.5 \%$ of study population had elevated ALT level of unknown etiology and found to have NAFLD. Previous studies reported that $66.6^{79}$ and $49.5 \%{ }^{80}$ cases with transaminitis had NAFLD. A study by Khurram and Ashraf ${ }^{57}$ revealed that presence of obesity, hepatomegaly, diabetes, and hypertriglyceridemia was characteristically associated with higher prevalence of NAFLD in community with majority of cases found in females. All the NAFLD cases presented with fatigability and $38 \%$ cases had NASH. A study by Abbas et al ${ }^{81}$ reported that cases with NAFLD were significantly older and had significantly higher BMI compared to controls. $21.8 \%$ cases with NAFLD had significantly raised ALT level and presence of NASH. ${ }^{81}$ A study by Luxmi et al ${ }^{82}$ reported that the prevalence of fatty liver in type-2 diabetics was $60.8 \%$, which was similar to that reported by Gupte et $\mathrm{al}^{13}$ in India (NAFLD prevalence in diabetics was $49 \%$ ). High BMI was found as an independent predictor of fatty liver. ${ }^{82}$ A study by Taseer et $\mathrm{al}^{83}$ reported that the prevalence of NAFLD in the diabetic patients was $51 \%$ and majority $(92.15 \%)$ of patients with NAFLD had hypertriglyceridemia and most common presentation of NAFLD was heaviness in the right upper abdomen (64.7\%).

\section{Bangladesh}

A study by Khan et $\mathrm{al}^{84}$ reported that the prevalence of NAFLD was $44 \%$, with majority (54\%) of cases found in male. Majority of cases (59.3\%) presented at the age of 40 to 60 years and MS was present in $61.5 \%$ of cases. ${ }^{84} \mathrm{~A}$ study by Alam et al, ${ }^{85}$ the largest study on NAFLD from Bangladesh, reported that common age of presentation of NAFLD was 30 to 50 years. Most cases were females and majority (96.2\%) cases had central obesity. Prevalence of NASH was $42.4 \%{ }^{85}$ in NAFLD cases, which is much higher compared to other published report. ${ }^{11}$ Presence of diabetes and high serum GGT could significantly predict presence of NASH. ${ }^{85}$

\section{Nepal}

A study by Mittal et $\mathrm{al}^{86}$ at Pokhara, Nepal reported that the prevalence of NAFLD was 17\%. Mild-to-moderate elevations in serum levels of aspartate aminotransferase (43.42-49.49 IU/L) and ALT (43.90-53.92 IU/L) were the most common laboratory abnormalities found in patients with NAFLD.

Prevalence, mean age of presentation, sex predominance, and associations with different metabolic parameters of NAFLD cases residing in South Asia are described in Tables 1 to $6 .^{87-95}$ 
Table 1: Prevalence of NAFLD in South Asia (India)

\begin{tabular}{lllllll}
\hline $\begin{array}{l}\text { Country } \\
\text { (region) }\end{array}$ & Population category & $\begin{array}{l}\text { Mode of } \\
\text { diagnosis }\end{array}$ & $\begin{array}{l}\text { No. of } \\
\text { subjects }(n)\end{array}$ & $\begin{array}{l}\text { Prevalence } \\
(\%)\end{array}$ & Authors & References \\
\hline East India & Asymptomatic healthy attendants & US study & 159 & 24.5 & Singh et al & 87 \\
North India & Hospital patients & US study & 2,156 & 4 & Anand et al & 88 \\
West India & General population & US study & 1,168 & 16.6 & Amarapurkar et al & 68 \\
East India & Gastroenterology patients & US study & 639 & 21.6 & Singh et al & 89 \\
South India & Urban general population & US study & 541 & 32 & Mohan et al & 28 \\
West India & Routine health checkup & US study & 1,003 & 22.6 & Uchil et al & 90 \\
North India & Laparotomy patients & Histology & 57 & 42 & Agrawal et al & 91 \\
North India & General autopsy & Histology & 100 & 40 & Bal et al & 92 \\
East India & Road traffic accident victims & Histology & 103 & 14.6 & Singh et al & 93 \\
North India & Healthy volunteers & US study & 121 & 32 & Bajaj et al & 70 \\
\hline
\end{tabular}

Table 2: Prevalence of NAFLD in other South Asian countries

\begin{tabular}{llllllc}
\hline Country (region) & Population category & $\begin{array}{l}\text { Mode of } \\
\text { diagnosis }\end{array}$ & $\begin{array}{l}\text { Number of } \\
\text { subjects }(n)\end{array}$ & $\begin{array}{l}\text { Prevalence } \\
\text { (\%) }\end{array}$ & Authors & References \\
\hline Pakistan (Rawalpindi) & $\begin{array}{l}\text { Ex-army personnel and their } \\
\text { dependents }\end{array}$ & US study & 207 & 50 & Bano et al & 80 \\
Pakistan (Karachi) & $\begin{array}{l}\text { Visitors attending hepatitis } \\
\text { awareness program }\end{array}$ & US study & 928 & 15.3 & Abbas et al & 81 \\
Pakistan (Karachi) & $\begin{array}{l}\text { Routine health checkup } \\
\text { Sri Lanka }\end{array}$ & US study & 952 & 13.5 & Niaz et al & 79 \\
Sri Lanka & Asymptomatic transamnitis & Histology & 296 & 35.1 & De Hewavisenthi et al & 76 \\
Sri Lanka (Nuwara & Rural physically active & US study & 2,985 & 32.6 & Dassanayake et al & 30 \\
Eliya) & population & US study & 403 & 18 & Pinidiyapathirage et al 31 \\
Bangladesh & Hospital-based study population & US study & 334 & 44 & Khan et al & 84 \\
Nepal (Pokhara) & Hospital-based study population & US study & 515 & 17 & Mittal et al & 86 \\
\hline
\end{tabular}

Table 3: Mean age of presentation and sex predominance among South Asian (Indian) NAFLD patients

\begin{tabular}{|c|c|c|c|c|c|}
\hline Country (regions) & $\begin{array}{l}\text { Numbers of } \\
\text { patients (n) }\end{array}$ & Sex predominance & $\begin{array}{l}\text { Mean age of } \\
\text { presentation (years) }\end{array}$ & Authors & References \\
\hline East India & 63 & Male & 42.7 & Singh et al & 89 \\
\hline West India & 730 & No sex predominance & 39.8 & Amarapurkar et al & 68 \\
\hline West India & 225 & Male & $\mathrm{Nm}$ & Uchil et al & 90 \\
\hline North India & 100 & Male & 37.8 & Duseja et al & 58 \\
\hline North India & 150 & Male & 42.2 & Bhat et al & 94 \\
\hline East India & 336 & Male & 41.7 & Singh et al & 75 \\
\hline East India & 515 & Male & $\begin{array}{l}46.6 \text { (Diabetic) } \\
40.4 \text { (Nondiabetic) }\end{array}$ & Singh et al & 74 \\
\hline East India & 632 & Male & 42.4 & Singh et al & 72 \\
\hline North India & 205 & Male & $\begin{array}{l}38 \text { (Lean) } \\
40.9 \text { (Obese) }\end{array}$ & Kumar et al & 73 \\
\hline
\end{tabular}

Nm: Not mentioned

Table 4: Mean age of presentation and sex predominance in other South Asian countries

\begin{tabular}{llllll}
\hline Country (regions) & $\begin{array}{l}\text { Numbers of } \\
\text { patients }(n)\end{array}$ & $\begin{array}{l}\text { Sex } \\
\text { predominance }\end{array}$ & $\begin{array}{l}\text { Mean age of } \\
\text { presentation (years) }\end{array}$ & Authors & References \\
\hline Pakistan (Rawalpindi) & 103 & Female & 45.3 & Bano et al & 80 \\
Pakistan (Karachi) & 128 & Nm & 39.2 & Niaz et al & 79 \\
Pakistan (Rawalpindi) & 50 & Female & 39.12 & Khurram and Ashraf & 57 \\
Pakistan (Karachi) & 142 & Male & 43.3 & Abbas et al & 81 \\
Sri Lanka & 103 & Male & 37.2 & De Hewavisenthi et al & 76 \\
Sri Lanka & 973 & Female & 52.8 & Dassanayake et al & 30 \\
Sri Lanka (Nuwara Eliya) & 73 & Male & 50.5 & Pinidiyapathirage et al & 31 \\
Bangladesh & 146 & Male & Nm & Khan et al & 84 \\
Bangladesh & 439 & Female & 40.8 & Alam et al & 85 \\
\hline
\end{tabular}

$\mathrm{Nm}$ : Not mentioned 
Nonalcoholic Fatty Liver Disease in South Asia

Table 5: Nonalcoholic fatty liver disease associations in South Asia (India)

\begin{tabular}{|c|c|c|c|c|c|c|c|}
\hline Region & $\begin{array}{l}\text { Number of } \\
\text { cases (n) }\end{array}$ & BMI in $\mathrm{kg} / \mathrm{m}^{2}$ (mean) & Obesity (\%) & Dysglycemia (\%) & MS (\%) & Authors & References \\
\hline Allahabad & 39 & 26.7 & 66.7 & 23.1 (IFG) & 41 & Bajaj et al & 70 \\
\hline Mumbai & 226 & 28.5 & 24.8 & 72.4 (IFG) & 47.1 & Uchil et al & 90 \\
\hline Chandigarh & 100 & $\mathrm{Nm}$ & 68 & $12(\mathrm{DM})$ & 50 & Duseja et al & 58 \\
\hline New Delhi & 51 & 26.7 & 69.4 & 10 (DM) & 20.9 & Madan et al & 15 \\
\hline Odisha & 39 & 25.9 & 12.8 & 41.7 (IR) & $\mathrm{Nm}$ & Singh et al & 87 \\
\hline Chandigarh & 127 & 28.7 & 68 & $\begin{array}{l}83 \text { (IR) } \\
13 \text { (DM) }\end{array}$ & 48 & Duseja et al & 95 \\
\hline Odisha & 336 & 26.3 & 68.7 & $\begin{array}{l}54.4 \text { (IR) } \\
19.9 \text { (DM) }\end{array}$ & 31.6 & Singh et al & 75 \\
\hline Odisha & 515 & $\begin{array}{l}26.3 \text { (Nondiabetic) } \\
26.6 \text { (Diabetic) }\end{array}$ & $\mathrm{Nm}$ & $\begin{array}{l}22.9 \text { (Prediabetic) } \\
24(\mathrm{DM})\end{array}$ & $\mathrm{Nm}$ & Singh et al & 74 \\
\hline Odisha & 632 & 26.1 & 61.7 & $\begin{array}{l}15.2(\mathrm{DM}) \\
54.4(\mathrm{IR})\end{array}$ & 40 & Singh et al & 72 \\
\hline New Delhi & 205 & $\begin{array}{l}21.3 \text { (Lean) } \\
28.3 \text { (Obese) }\end{array}$ & 68.7 & $\begin{array}{l}3.7 \text { (Lean diabetic) } \\
7.4 \text { (Lean IR) } \\
26 \text { (Obese diabetic) } \\
61 \text { (Obese IR) }\end{array}$ & $\begin{array}{l}22 \text { (Lean) } \\
64 \text { (Obese) }\end{array}$ & Kumar et al & 73 \\
\hline
\end{tabular}

BMI: Body mass index; IFG: Impaired fasting glucose; MS: Metabolic syndrome; IR: Insulin resistance; DM: Diabetes mellitus; Nm: Not mentioned

Table 6: Nonalcoholic fatty liver disease association in other South Asian countries

\begin{tabular}{|c|c|c|c|c|c|c|c|}
\hline Country (location) & Case (n) & $\begin{array}{l}\mathrm{BMI} \mathrm{kg} / \mathrm{m}^{2} \\
(\text { mean) }\end{array}$ & Obesity (\%) & Dysglycemia (\%) & MS (\%) & Authors & References \\
\hline \multirow[t]{2}{*}{ Pakistan (Rawalpindi) } & 103 & $31.3(F)$ & 66 & 34 (DM) & 28 & Bano et al & 80 \\
\hline & & $27.7(\mathrm{M})$ & & & & & \\
\hline Pakistan (Rawalpindi) & 50 & 32.6 & 54 & 30 (DM) & $\mathrm{Nm}$ & Khurram and Ashraf & 57 \\
\hline Pakistan (Karachi) & 142 & 28.6 & 77.46 & 9.85 (DM) & $\mathrm{Nm}$ & Abbas et al & 81 \\
\hline Pakistan (Karachi) & 128 & 27.1 & $\mathrm{Nm}$ & $\mathrm{Nm}$ & $\mathrm{Nm}$ & Niaz et al & 79 \\
\hline Sri Lanka & 103 & $\mathrm{Nm}$ & 52 & 55 (DM) & $\mathrm{Nm}$ & De Hewavisenthi et al & 76 \\
\hline Sri Lanka & 973 & 27.1 & 69 & 66.9 (IFG) & $\mathrm{Nm}$ & Dassanayake et al & 30 \\
\hline Sri Lanka (Nuwara Eliya) & 73 & $\mathrm{Nm}$ & $\mathrm{Nm}$ & 43.5 (IR) & $\mathrm{Nm}$ & Pinidiyapathirage et al & 31 \\
\hline Bangladesh & 146 & $\mathrm{Nm}$ & $\mathrm{Nm}$ & $\mathrm{Nm}$ & 61.5 & Khan et al & 84 \\
\hline Bangladesh & 439 & $\mathrm{Nm}$ & 75.1 & $16.8(\mathrm{DM})$ & 42.9 & Alam et al & 85 \\
\hline
\end{tabular}

N: Number; M: Male; F: Female; MS: Metabolic syndrome; IFG: Impaired fasting glucose; DM: Diabetes mellitus; IR: Insulin resistance; $\mathrm{Nm}$ : Not mentioned

\section{CONCLUSION}

Nonalcoholic fatty liver disease represents only the tip of iceberg, what we see, whereas it reflects the ongoing devastating process inside the body, i.e., occurrence of MS or increased risk for its occurrence in body with time if not properly managed at an early stage, which is essentially a preventable condition. This review highlights the fact that the South Asians are at increased risk of having NAFLD and NASH and these should be searched even in nonobese individuals, as, despite absence of frank obesity in South Asians, compared to other ethnic population, they are relatively more metabolically obese and more prone to develop NAFLD and related complications compared to other ethnic populations. Therefore, the costeffective US of abdomen should be included in the list of tests for persons undergoing health or preemployment checkups for early diagnosis of NAFLD in this resourceconstraint South Asian region, so that early necessary measures can be undertaken to reduce NAFLD associated morbidity and mortality in the community. Whether residing in the East or West, the South Asians seem to be at very high risk to suffer from fatty liver compared to Caucasians. In the West, patients with NAFLD were usually old, females, and obese, whereas South Asians with NAFLD were usually young, males, and nonobese. Nonalcoholic fatty liver disease is likely to soon become the largest contributor of liver-related morbidity and mortality like it is in the West. Pharmacological therapy for NAFLD is still evolving and large-scale primary prevention health education strategy and lifestyle programs are required to stem this tide, while further research is to be done to identify missing links in the pathogenesis and treatment of NAFLD in future. 


\section{REFERENCES}

1. Ludwig J, Viggiano TR, McGill DB, Oh BJ. Nonalcoholic steatohepatitis: Mayo Clinic experiences with a hitherto unnamed disease. Mayo Clin Proc 1980 Jul;55(7):434-438.

2. Neuschwander-Tetri BA. Nonalcoholic steatohepatitis and the metabolic syndrome. Am J Med Sci 2005 Dec;330(6):326-335.

3. Marchesini G, Bugianesi E, Forlani G, Cerrelli F, Lenzi M, Manini R, Natale S, Vanni E, Villanova N, Melchionda N, et al. Nonalcoholic fatty liver, steatohepatitis, and the metabolic syndrome. Hepatology 2003 Apr;37(4):917-923.

4. Grattagliano I, Portincasa P, Palmieri VO, Palasciano G. Managing nonalcoholic fatty liver disease: recommendations for family physicians. Can Fam Physician 2007 May;53(5):857-863.

5. Browning JD, Szczepaniak LS, Dobbins R, Nuremberg P, Horton JD, Cohen JC, Grundy SM, Hobbs HH. Prevalence of hepatic steatosis in an urban population in the United States: impact of ethnicity. Hepatology 2004 Dec;40(6):1387-1395.

6. Angulo P. GI epidemiology: nonalcoholic fatty liver disease. Aliment Pharmacol Ther 2007 Apr 15;25(18):883-889.

7. Jafar TH, Hatcher J, Poulter N, Islam M, Hashmi S, Qadri Z, Bux R, Khan A, Jafary FH, Hameed A, et al. Communitybased interventions to promote blood pressure control in a developing country: a cluster randomized trial. Ann Intern Med 2009 Nov 3;151(9):593-601.

8. Lear SA, Toma M, Birmingham CL, Frolich JJ. Modification of the relationship between simple anthropometric indices and risk factors by ethnic background. Metabolism 2003 Oct;52(10):1295-1301.

9. Hamaguchi M,Kojima T, Takeda N, Nakagawa T, Taniguchi H, Fujii K, Omatsu T, Nakajima T, Sarui H, Shimazaki M, et al. The metabolic syndrome as a predictor of nonalcoholic fatty liver disease. Ann Intern Med 2005 Nov 15;143(10):722-728.

10. Sanyal AJ. American Gastroenterological Association. AGA technical review on nonalcoholic fatty liver disease. Gastroenterology 2002 Nov;123(5):1705-1725.

11. McCullough AJ. The epidemiology and risk factors of NASH. In: Farrell GC, George J, de la Hall P, McCullough AJ, editors. Fatty liver disease: NASH and related disorders. Malden (MA): Blackwell Publishing; 2005. p. 23-37.

12. Park SH, Kim BI, Yun JW, Kim JW, Park DI, Cho YK, Sung IK, Park CY, Sohn CI, Jeon WK, et al. Insulin resistance and C reactive protein as independent risk factors for non alcoholic fatty liver disease in non-obese Asian men. J Gastroenterol Hepatol 2004 Jun;19(6):694-698.

13. Gupte P, Amarapurkar D, Agal S, Baijal R, Kulshreshtta P, Pramanik S, Patel N, Madan A, Amarapurkar A, Hafeezunnisa. Non-alcoholic steatohepatitis in type 2 diabetes mellitus. J Gastroenterol Hepatol 2004 Aug;19(8):854-858.

14. Shen L, Fan JG, Shao Y, Zeng MD, Wang JR, Luo GH, Li JQ, Chen SY. Prevalence of non-alcoholic fatty liver among administrative officers in Shanghai: an epidemiological survey. World J Gastroenterol 2003 May;9(5):1106-1110.

15. Madan K, Batra Y, Gupta SD, Chander B, Rajan KD, Tewatia MS, Panda SK, Acharya SK. Non-alcoholic fatty liver disease may not be a severe disease at presentation among Asian Indians. World J Gastroenterol 2006 Jun 7;12(21):3400-3405.

16. Duvnjak M, Leroti I, Barsi N, Tomasi V, Virovi Juki L, Velagi V. Pathogenesis and management issues for nonalcoholic fatty liver disease. World J Gastroenterol 2007 Sep 14;13(34):4539-4550.

17. Siebler J, Galle PR, Weber MM. The gut-liver-axis: endotoxemia, inflammation, insulin resistance and NASH. J Hepatol 2008 Jun;48(6):1032-1034.
18. Angulo P. Nonalcoholic fatty liver disease. N Engl J Med 2002 Apr 18;346(16):1221-1231.

19. Farrell GC, Chitturi S, Lau GK, Sollano JD. Guidelines for the assessment and management of non-alcoholic fatty liver disease in the Asia-Pacific region: executive summary. J Gastroenterol Hepatol 2007 Jun;22(6):775-777.

20. Hamaguchi M, Kojima T, Itoh $Y$, Harano Y, Fujii K, Nakajima T, Kato T, Takeda N, Okuda J, Ida K, et al. The severity of ultrasonographic findings in nonalcoholic fatty liver disease reflects the metabolic syndrome and visceral fat accumulation. Am J Gastroenterol 2007 Dec;102(12):2708-2715.

21. Chitturi S, Farrell GC, Hashimoto E, Saibara T, Lau GK, Sollano JD. Nonalcoholic fatty liver disease in the Asia-Pacific region: definitions and overview of proposed guidelines. J Gastroenterol Hepatol 2007 Jun;22(6):778-787.

22. Johnson NA, George J. Fitness versus fatness: moving beyond weight loss in nonalcoholic fatty liver disease. Hepatology 2010 Jul;52(1):370-381.

23. Adams LA, Angulo P. Treatment of non-alcoholic fatty liver disease. Postgrad Medl J 2006 May;82(967):315-322.

24. Angulo P, Lindor KD. Treatment of nonalcoholic fatty liver: present and emerging therapies. Semin Liver Dis 2001;21(1):81-88.

25. Furuya CK Jr, de Oliveira CP, de Mello ES, Faintuch J, Raskovski A, Matsuda M, Vezozzo DC, Halpern A, Garrido AB Jr, Alves VA, et al. Effects of bariatric surgery on nonalcoholic fatty liver disease: preliminary findings after 2 years. J Gastroenterol Hepatol 2007 Apr;22(4):510-514.

26. Mathurin P, Hollebecque A, Arnalsteen L, Buob D, Leteurtre E, Caiazzo R, Pigeyre M, Verkindt H, Dharancy S, Louvet A, et al. Prospective study of the long-term effects of bariatric surgery on liver injury in patients without advanced disease. Gastroenterology 2009 Aug;137(2):532-540.

27. McKeigue PM, Shah B, Marmot MG. Relation of central obesity and insulin resistance with high diabetes prevalence and cardiovascular risk in South Asians. Lancet 1991 Feb 16;337(8738):382-386.

28. Mohan V, Farooq S, Deepa M, Ravikumar R, Pitchumoni CS. Prevalence of non-alcoholic fatty liver disease in urban south Indians in relation to different grades of glucose intolerance and metabolic syndrome. Diabetes Res Clin Pract 2009 Apr;84(1):84-91.

29. Das K, Das K, Mukherjee PS, Ghosh A, Ghosh S, Mridha AR, Dhibar T, Bhattacharya B, Bhattacharya D, Manna B, et al. Non obese population in a developing country has a high prevalence of non-alcoholic fatty liver and significant liver disease. Hepatology 2010 May;51(5):1593-1602.

30. Dassanayake AS, Kasturiratne A, Rajindrajith S, Kalubowila U, Chakrawarthi S, De Silva AP, Makaya M, Mizoue T, Kato N, Wickremasinghe AR, et al. Prevalence and risk factors for non-alcoholic fatty liver disease among adults in an urban Sri Lankan population. J Gastroenterol Hepatol 2009 Jul;24(7):1284-1288.

31. Pinidiyapathirage MJ, Dassanayake AS, Rajindrajith $S$, Kalubowila U, Kato N, Wickremasinghe AR, Silva HJD. Nonalcoholic fatty liver disease in a rural, physically active, low income population in Sri Lanka. BMC Res Notes 2011 Nov 24;4:513.

32. Banerji MA, Faridi N, Alturi R, Chaiken RL, Lebovitz HE. Body composition, visceral fat, leptin and insulin resistance in Asian Indian men. J Clin Endocrinol Metab 1999 Jan;84(1):137-144. 
33. Liu CJ. Prevalence and risk factors for NAFLD in Asian people who are not obese. J Gastroenterol Hepatol 2012 Oct;27(10):1555-1560.

34. McKeigue PM, Pierpoint T, Ferrie JE, Marmot MG. Relationship of glucose intolerance and hyperinsulinaemia to body fat pattern in South Asians and Europeans. Diabetologia 1992 Aug;35(8):785-791.

35. Misra A. Body composition and the metabolic syndrome in Asian Indians: a saga of multiple adversities. Natl Med J India 2003 Jan-Feb;16(1):3-7.

36. Misra A, Athiko D, Sharma R, Pandey RM, Khanna N. Nonobese hyperlipidemic Asian northern Indian males have adverse anthropometric profile. Nutr Metab Cardiovasc Dis 2002 Aug;12(4):178-183.

37. Mohan V, Sharp PS, Cloke HR, Burrin JM, Schumer B, Kohner EM. Serum immunoreactive insulin responses to a glucose load in Asian Indian and European type 2 (noninsulin-dependent) diabetic patients and control subjects. Diabetologia 1986 Apr;29(4):235-237.

38. Sharp PS, Mohan V, Levy JC, Mather HM, Kohner EM. Insulin resistance in patients of Asian Indian and European origin with non-insulin dependent diabetes. Horm Metab Res 1987 Feb;19(2):84-85.

39. Kamath SK, Hussain EA, Amin D, Mortillaro E, West B, Peterson CT, Aryee F, Murillo G, Alekel DL. Cardiovascular disease risk factors in 2 distinct ethnic groups: Indian and Pakistani compared with American premenopausal women. Am J Clin Nutr 1999 Apr;69(4):621-631.

40. Weston SR, Leydon W, Murphy R, Bass NM, Bell BP, Manos MM, Terrault NA. Racial and ethnic distribution of nonalcoholic fatty liver in persons with newly diagnosed chronic liver disease. Hepatology 2005 Feb;41(2):372-379.

41. Petersen KF, Dufour S, Feng J, Befroy D, Dziura J, Dalla Man C, Cobelli C, Shulman GI. Increased prevalence of insulin resistance and nonalcoholic fatty liver disease in Asian-Indian men. Proc Natl Acad Sci USA 2006 Nov 28;103(48):1827-1837.

42. Misra A. Impact of ethnicity on body fat patterning in Asian Indians and Blacks: relationship with insulin resistance. Nutrition 2003 Sep;19(9):815-816.

43. Misra A, Vikram NK, Arya S, Pandey RM, Dhingra V, Chatterjee A, Dwivedi M, Sharma R, Luthra K, Guleria R, et al. High prevalence of insulin resistance in postpubertal Asian Indian children is associated with adverse truncal body fat patterning, abdominal adiposity and excess body fat. Int J Obes Relat Metab Disord 2004 Oct;28(10):1217-1226.

44. Yajnik CS, Lubree HG, Rege SS, Naik SS, Deshpande JA, Deshpande SS, Joglekar CV, Yudkin JS. Adiposity and hyperinsulinemia in Indians are present at birth. J Clin Endocrinol Metab 2002 Dec;87(12):5575-5580.

45. Misra A, Nishanth S, Pasha ST, Pandey RM, Sethi P, Rawat DS. Relationship of Xba1 and EcoR1 polymorphisms of apolipoprotein-B gene to dyslipidemia and obesity in Asian Indians in North India. Indian Heart J 2001 Mar-Apr;53(2):177-183.

46. Renges HH, Wile DB, McKeigue PM, Marmot MG, Humphries SE. Apolipoprotein B gene polymorphisms are associated with lipid levels in men of South Asian descent. Atherosclerosis $1991 \mathrm{Dec} ; 91(3): 267-275$.

47. Miller M, Rhyne J, Khatta M, Parekh H, Zeller K. Prevalence of the APOC3 promoter polymorphisms T-455C and C-482T in Asian-Indians. Am J Cardiol 2001 Jan 15;87(2):220-221, A8.

48. Saha N, Tay JS, Heng CK, Humphries SE. DNA polymorphisms of the apolipoprotein B gene are associated with obesity and serum lipids in healthy Indians in Singapore. Clin Genet 1993 Sep;44(3):113-120.

49. Misra A, Khurana L. Obesity and the metabolic syndrome in developing countries. J Clin Endocrinol Metab 2008 Nov;93 (11 Suppl 1):S9-S30.

50. Chandalia M, AbateN, Garg A, Stray-Gundersen J, Grundy SM. Relationship between generalized and upper body obesity to insulin resistance in Asian Indian men. J Clin Endocrinol Metab 1999 Jul;84(7):2329-2335.

51. Raji A, Seely EW, Arky RA, Simonson DC. Body fat distribution and insulin resistance in healthy Asian Indians and Caucasians. J Clin Endocrinol Metab 2001 Nov;86(11): 5366-5371.

52. Misra A, Vikram NK. Insulin resistance syndrome (metabolic syndrome) and obesity in Asian Indians: evidence and implications. Nutrition 2004 May;20(5):482-491.

53. Wasir JS, Misra A. The metabolic syndrome in Asian Indians: the impact of nutritional and socioeconomic transition in India. Metab Syndr Relat Disord 2004 Spring;2(1):14-23.

54. Sevak L, McKeigue PM, Marmot MG. Relationship of hyperinsulinemia to dietary intake in South Asian European men. Am J Clin Nutr 1994 May;59(5):1069-1074.

55. Schwimmer JB, Celedon MA, Lavine JE, Salem R, Campbell N, SchorkNJ, Shiehmorteza M, Yokoo T, Chavez A, Middleton MS, et al. Heritability of nonalcoholic fatty liver disease. Gastroenterology 2009 May;136(5):1585-1592.

56. Matteoni CA, Younossi ZM, Gramlich T, Boparai N, Liu YC, McCullough AJ. Nonalcoholic fatty liver disease: a spectrum of clinical and pathological severity. Gastroenterology 1999 Jun;116(6):1413-1419.

57. Khurram M, Ashraf MM. A clinical and biochemical profile of biopsy-proven non-alcoholic fatty liver disease subjects. J Coll Physicians Surg Pak 2007 Sep;17(9):531-534.

58. Duseja A, Das A, Das R, Dhiman RK, Chawla Y, Bhansali A, Kalra N. The clinicopathological profile of Indian patients with nonalcoholic fatty liver disease (NAFLD) is different from that in the West. Dig Dis Sci 2007 Sep;52(9):2368-2374.

59. Misra A, Jaiswal A, Shakti D, Wasir J, Vikram NK, Pandey RM, Kondal D, Bhushan B. Novel phenotypic markers and screening score for the metabolic syndrome in adult Asian Indians. Diabetes Res Clin Pract 2008 Feb;79(2):e1-e5.

60. Misra A, Khurana L. The metabolic syndrome in South Asians: epidemiology, determinants, and prevention. Metab Syndr Relat Disord 2009 Dec;7(6):497-514.

61. Chambers JC, Eda S, Bassett P, Karim Y, Thompson SG, Gallimore JR, Pepys MB, Kooner JS. C-reactive protein, insulin resistance, central obesity, and coronary heart disease risk in Indian Asians from the United Kingdom compared with European whites. Circulation 2001 Jul 10;104(2):145-150.

62. Babusik P, Bilal M, Duris I. Nonalcoholic fatty liver disease of two ethnic groups in Kuwait: comparison of prevalence and risk factors. Med Princ Pract 2012;21(1):56-62.

63. Misra A, Misra R, Wijesuriya M, Banerjee D. The metabolic syndrome in South Asians: continuing escalation \& possible solutions. Indian J Med Res 2007 Mar;125(3):345-354.

64. Misra A, Vikram NK. Insulin resistance syndrome (metabolic syndrome) and Asian Indians. Curr Sci 2002 Dec 25;83(12):1483-1496.

65. Duseja A, Das A, Das R, Dhiman R, Chawla Y. Nonalcoholic steatohepatitis: our experience. Indian J Gastroenterol 2004;23(Suppl 1):S25. 
66. Agarwal SR, Malhotra V, Sakhuja P, Sarin S. Clinical biochemical and histological profile of nonalcoholic steatohepatitis. Indian J Gastroenterol 2001 Sep-Oct;20(5):183-186.

67. Madan K, Batra Y, Panda SK, Dattagupta S, Hazari S, Jha JK, Acharya SK. Role of polymerase chain reaction and liver biopsy in the evaluation of patients with asymptomatic transaminitis: implications in diagnostic approach. J Gastroenterol Hepatol 2004 Nov;19(11):1291-1299.

68. Amarapurkar D, Kamani P, Patel N, Gupte P, Kumar P, Agal S, Baijal R, Lala S, Chaudhary D, Deshpande A. Prevalence of non-alcoholic fatty liver disease: population based study. Ann Hepatol 2007 Jul-Sep;6(3):161-163.

69. Amarapurkar DN, Patel ND. Clinical spectrum of nonalcoholic steatohepatitis with normal aminotransferase values. Trop Gastroenterol 2004 Jul-Sep;25(3):132-134.

70. Bajaj S, Nigam P, Luthra A, Pandey RM, Kondal D, Bhatt SP, Wasir JS, Misra A. A case-control study on insulin resistance, metabolic co-variates \& prediction score in non-alcoholic fatty liver disease. Indian J Med Res 2009 Mar;129(3):285-292.

71. Nigam P, Bhatt SP, Misra A, Vaidya M, Dasgupta J, Chadha DS. Non-alcoholic fatty liver disease is closely associated with sub-clinical inflammation: a case-control study on Asian Indians in North India. PLoS One 2013;8(1):e49286.

72. Singh SP, Kar SK, Panigrahi MK, Misra B, Pattnaik K, Bhuyan P, Meher C, Agrawal O, Rout N, Swain M. Profile of patients with incidentally detected nonalcoholic fatty liver disease (IDNAFLD) in coastal eastern India. Trop Gastroenterol 2013 Jul-Sep;34(3):144-152.

73. Kumar R, Rastogi A, Sharma MK, Bhatia V, Garg H, Bihari C, Sarin SK. Clinicopathological characteristics and metabolic profiles of non-alcoholic fatty liver disease in Indian patients with normal body mass index: do they differ from obese or overweight non-alcoholic fatty liver disease? Indian J Endocr Metab 2013 Jul;17(4):665-671.

74. Singh SP, Singh A, Pati GK, Misra B, Misra D, Kar SK, Panigrahi MK, Meher C, Agrawal OP, Rout N, et al. A study of prevalence of diabetes and prediabetes in patients of nonalcoholic fatty liver disease and the impact of diabetes on liver histology in Coastal Eastern India. J Diabetes Mellitus 2014 Nov;4(4):290-296.

75. Singh SP, Misra B, Kar SK, Panigrahi MK, Misraa D, Bhuyan P, Pattnaik K, Meher C, Agrawal OP, Rout N, et al. Nonalcoholic fatty liver disease (NAFLD) without insulin resistance: is it different? Clin Res Hepatol Gastroenterol 2015 Sep;39(4):482-488.

76. De Hewavisenthi SJ, Dassanayaka AS, De Silva HJ. Clinical, biochemical and histological characteristics of a Sri Lankan population of non-alcoholic steatohepatitis (NASH) patients. Ceylon Med J 2005 Sep;50(3):113-116.

77. Pappas G, Akhtar T, Gergen PJ, Hadden WC, Khan AQ. Health status of the Pakistani population: a health profile and comparison with the United States. Am J Public Health 2001 Jan;91(1):93-98.

78. Butt AS, Hamid S, Jafri W, Salih M, Javed A. Prevalence and risk factors for NAFLD among native South Asian Pakistani patients with type II diabetes and metabolic syndrome. United Eur Gastroenterol Week 2011:Abstract No. 11-6979.

79. Niaz A, Ali Z, Nayyar S, Fatima N. Prevalence of NAFLD in healthy and young male individuals. ISRN Gastroenterol 2011;2011:363546.
80. Bano U, Gondal M, Moin S. Evaluation of risk factors of non alcoholic fatty liver disease (NAFLD) in a tertiary care hospital at Rawalpindi, Pakistan: a local experience. JPMI 2008;22(3): 189-195.

81. Abbas Z, Saeed A, Hassan SM, Luck NH, Khan A, Zafar MN, Hossain KZ, Faiq SM. Non-alcoholic fatty liver disease among visitors to a hepatitis awareness programme. Trop Gastroenterol 2013 Jul-Sep;34(3):153-158.

82. Luxmi S, Sattar RA, Ara J. Association of non alcoholic fatty liver with type 2 diabetes mellitus. JLUMHS 2008: 188-193.

83. Taseer IH, Hussain L, Safdar S, Mirbahar AM, Ahmad I. Frequency of non alcoholic fatty liver disease (NAFLD) and its biochemical derangements in type-2 diabetic patients. Pak J Med Sci 2009;25(5):817-820.

84. Khan MMR, Chowdhury MAJ, Rashid MH, Rahman MK, Chowdhury MMH, Alim MA, Islam QT. Nonalcoholic fatty liver disease in metabolic syndrome among patients attending in a tertiary care center in Bangladesh. Hepatol Int 2011;5:3-558.

85. Alam S, Noor-E-Alam SM, Chowdhury ZR, Alam M, Kabir J. Nonalcoholic steatohepatitis in nonalcoholic fatty liver disease patients of Bangladesh. World J Hepatol 2013 May 27;5(5):281-287.

86. Mittal A, Sathian B,Chandrasekharan N, Lekhi A, Farooqui MS, Pandey N. Diagnostic accuracy of serological markers in viral hepatitis and non alcoholic fatty liver disease: a comparative study in tertiary care hospital of Western Nepal. Nepal J Epidemiol 2011;1(2):60-63.

87. Singh SP, Nayak S, Swain M, Rout N, Mallik RN, Agrawal O, Meher C, Rao M. Prevalence of nonalcoholic fatty liver disease in coastal eastern India: a preliminary ultrasonographic survey. Trop Gasteroenterol 2004 Apr-Jun;25(2):76-79.

88. Anand AC, Chawla Y, Amarapurkar D. Nonalcoholic steatohepatitis. Trop Gastroenterol 2002;24:186-189.

89. Singh SP, Nayak SN, Swain M, et al. US study of prevalence of NAFLD in coastal eastern India. Indian J Gastroenterol 2004;23(Suppl 2):A47.

90. Uchil D, Pipalia D, Chawla M, Patel R, Maniar S, Narayani, Juneja A. Non-alcoholic fatty liver disease (NAFLD) - the hepatic component of metabolic syndrome. J Assoc Physicians India 2009 Mar;57:201-204.

91. Agrawal R, Mishra S, Dixit VK, Rai S. Association of nonalcoholic fatty liver disease with obesity. Indian J Prev Soc Med 2008;39:13-16.

92. Bal MS, Singh SP, Bodal VK, Oberol SS, Surinder K. Pathological finding in liver autopsy. J Indian Assoc Forensic Med 2004;26:55-57.

93. Singh SP, Panda CR, Swain M, et al. A study of the prevalence of fatty liver disease (NAFLD) in fatal traffic casualties in coastal Orissa. J Gastroenterol Hepatol 2004;19(Suppl):A838.

94. Bhat G, Pandey A, Baba CS, et al. Metabolic syndrome in NAFLD patients: in Indian perspective [Abstract]. INASL 2006:A42.

95. Duseja A, Das A, Dhiman RK, Chawla YK, Das R, Bhadada S, Sialy R, Thumburu KK, Bhansali A, Kalra N. Indian patients with nonalcoholic fatty liver disease presenting with raised transaminases are different at presentation. World J Gastroenterol 2007 Jan 28;13(4):649-650. 